\title{
Caspase inhibitors: viral, cellular and chemical
}

\author{
BA Callus ${ }^{*, 1}$ and DL Vaux ${ }^{1}$
}

\begin{abstract}
Caspases, key mediators of apoptosis, are a structurally related family of cysteine proteases that cleave their substrates at aspartic acid residues either to cause cell death or to activate cytokines as part of an immune response. They can be controlled upstream by the regulation of signals that lead to zymogen activation, or downstream by inhibitors that prevent them from reaching their substrates. This review specifically looks at caspase inhibitors as distinct from caspase regulators: those produced by the cell itself; those whose genes are carried by viruses; and artificial caspase inhibitors used for research and potentially as therapeutics.
\end{abstract}

Cell Death and Differentiation (2007) 14, 73-78. doi:10.1038/sj.cdd.4402034; published online 8 September 2006

The first caspase inhibitor was discovered before caspases were termed 'caspases', and before caspases were known to be the key executioners of the cell death program. Caspase 1 , initially called interleukin $1 \beta$ converting enzyme (ICE), was identified not because it was involved in cell death, but because it is responsible for cleaving and thereby activating interleukin $1 \beta$, a pro-inflammatory cytokine. ${ }^{1,2}$ The first caspase inhibitor was cytokine response modifier $\mathrm{A}(\mathrm{CrmA})$, a product of cowpox virus that inhibits ICE activity. ${ }^{3}$

With the cloning of the CED-3, which is essential for programmed cell death in Caenorhabditis elegans, and recognition of its similarity to $\mathrm{ICE},{ }^{4}$ it became clear that caspases were required for cell death in the worm, and therefore that caspase inhibitors might prevent worm cells from killing themselves. Because the mechanisms of programmed cell death in the worm were similar to those for apoptosis of mammalian cells, ${ }^{5}$ caspase inhibitors could presumably prevent the death of mammalian cells as well.

The only caspase inhibitor known at the time, CrmA, was therefore tested for its ability to prevent cell death, and indeed, it was able to inhibit death of mammalian cells triggered by overexpression of caspase $1 .{ }^{6}$

The study of other viruses led to the identification of further caspase inhibitors, and pointed the way to identification of their cellular homologues. As several of the viral caspase inhibitors act through binding of pseudosubstrate loops in the catalytic site, study of viral caspase inhibitors has also provided useful examples for the design of artificial caspase inhibitors.

\section{CrmA}

Viruses that bear genes for caspase inhibitors have been positively selected either because the caspase inhibitors prolong host cell viability, increasing the time for viral replication or because caspase inhibition prevents the generation of inflammatory cytokines as part of the host's immune response.

CrmA inhibits caspase 1 , thus preventing the generation of active cytokines interleukin $1 \beta$ and interleukin $18 .^{7,8}$ In addition to inhibiting mammalian cell death caused by artificial overexpression of caspase 1 , it was later found that $\mathrm{CrmA}$ could inhibit apoptosis triggered by tumour necrosis factor (TNF) treatment or ligation of Fas receptors. ${ }^{9-12}$ In retrospect, however, it has turned out this was due to inhibition of caspase 8 by CrmA, rather than by inhibition of caspase 1 .

In addition to inhibiting caspase 1 with an inhibitory constant $\left(K_{\mathrm{i}}\right)$ in the low picomolar (pM) range (Table 1$)$, CrmA can also efficiently inhibit caspase 8 and in humans caspase 10 , and can thereby often prevent death of cells signalled by ligation of a subset of the TNF receptor super family members known as 'death receptors' that signal via FADD and caspase $8{ }^{32} \mathrm{CrmA}$ is not a strong inhibitor of other caspases, such as caspase 3 , 6 and $7\left(K_{\mathrm{i}}>100 \mathrm{nM}\right.$; Table 1$)$, and is therefore unlikely to be expressed at high enough levels to inhibit these capases in vivo. ${ }^{8}$

Although CrmA inhibits caspases, which are cysteine proteases, by structure and mechanism of action it is a member of the serine protease inhibitor (serpin) family, whose other members, as their name implies, inhibit serine proteases, rather than cysteine proteases. The pseudosubstrate residues $\left(P_{4}-P_{1}\right)$ of CrmA, LVAD, bind to the caspases' active sites (Figure 1a). Unbound CrmA is relatively unstable, but is significantly more stable while bound to caspase 1 . It is thought that some CrmA molecules are cleaved and subsequently released from caspase 1, whereas other CrmA molecules are not cleaved but form an irreversibly stable complex. ${ }^{13,33}$

BAC and DLV have no financial interests in any of the companies mentioned in this review.

${ }^{1}$ Department of Biochemistry, La Trobe University, Victoria 3086, Australia

${ }^{*}$ Corresponding author: BA Callus, Department of Biochemistry, La Trobe University, Victoria 3086, Australia. Tel: +61 39479 1669;

Fax: + 6139479 2467; E-mail: b.callus @latrobe.edu.au

Keywords: caspase; IAP; apoptosis; protease; p35

Abbreviations: ICE, interleukin $1 \beta$ converting enzyme; CrmA, cytokine response modifier A; TNF, tumour necrosis factor; IAP, inhibitor of apoptosis protein; BIR, baculoviral IAP repeat

Received 07.6.06; revised 27.7.06; accepted 27.7.06; Edited by S Kumar; published online 08.9.06 
Table 1 Specificity of viral and cellular caspase inhibitors

\begin{tabular}{|c|c|c|c|c|}
\hline $\begin{array}{l}\text { Caspase } \\
\text { inhibitor }\end{array}$ & Source & Target caspase(s) & $\begin{array}{l}\text { Strength of inhibition (where } \\
\text { known) }\end{array}$ & Reference \\
\hline CrmA & Cowpox virus & $\begin{array}{l}\text { Caspase } 1 \\
\text { Caspase } 8 \\
\text { Caspase } 10\end{array}$ & $\begin{array}{l}K_{\mathrm{i}} 4-10 \mathrm{pM} \\
K_{\mathrm{i}}<340 \mathrm{pM} \\
K_{\mathrm{i}} 4-17 \mathrm{nM}\end{array}$ & $13-15$ \\
\hline P35 & Baculovirus & $\begin{array}{l}\text { Broad spectrum, for example, inhibits caspase 1, 3, 6, 8, } \\
7 \text { and } 10\end{array}$ & $K_{\mathrm{i}} \mathrm{s} 0.1-9 \mathrm{nM}$ & 14,16 \\
\hline P49 & & $\begin{array}{l}\text { Broad spectrum } \\
\text { Caspase inhibitor, like p35, but also inhibits initiator } \\
\text { caspases DRONC and caspase } 9\end{array}$ & & 17,18 \\
\hline OplAP & Baculovirus & Does not directly inhibit caspase activity & & 19 \\
\hline DIAP1 & Drosophila & $\begin{array}{l}\text { DRONC } \\
\text { DrICE }\end{array}$ & $\begin{array}{l}\text { Powerfully inhibits DRONC activation; } \\
\text { activity against DrICE may be weak }\end{array}$ & $20-23$ \\
\hline XIAP & Mammalian & $\begin{array}{l}\text { Caspase } 3 \\
\text { Caspase } 7 \\
\text { Caspase } 9\end{array}$ & $\begin{array}{l}\text { IC50 } 0.1-2 \mathrm{nM} \\
\text { IC50 1-10 nM } \\
\text { IC50 10nM }\end{array}$ & $24-28$ \\
\hline clAP1 & Mammalian & $\begin{array}{l}\text { Does not directly inhibit caspases at physiological } \\
\text { concentrations }\end{array}$ & & 29 \\
\hline clAP2 & Mammalian & $\begin{array}{l}\text { Does not directly inhibit caspases at physiological } \\
\text { concentrations }\end{array}$ & & 29 \\
\hline ILP-2 & Human & $\begin{array}{l}\text { Does not directly inhibit caspases at physiological } \\
\text { concentrations }\end{array}$ & & 28 \\
\hline ML-IAP & Mammalian & $\begin{array}{l}\text { Does not directly inhibit caspases at physiological } \\
\text { concentrations }\end{array}$ & & 30 \\
\hline Survivin & Mammalian & $\begin{array}{l}\text { Does not directly inhibit caspases at physiological } \\
\text { concentrations }\end{array}$ & & 31 \\
\hline NAIP & Mammalian & $\begin{array}{l}\text { Does not directly inhibit caspases at physiological } \\
\text { concentrations }\end{array}$ & & 29 \\
\hline BRUCE & Mammalian & $\begin{array}{l}\text { Does not directly inhibit caspases at physiological } \\
\text { concentrations }\end{array}$ & & 29 \\
\hline
\end{tabular}

a catalytic site inhibition

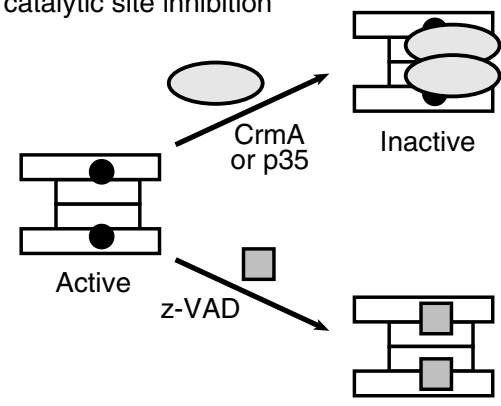

Inactive

b

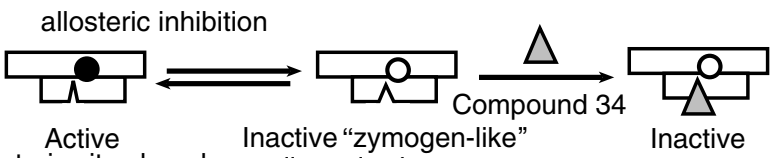
allosteric site closed allosteric site open

Figure 1 Catalytic site and allosteric site inhibition of caspases. (a) The viral inhibitors, CrmA and p35, as well as synthetic peptidic inhibitors for example, z-VAD-fmk, bind as pseudosubstrates to the active catalytic sites (solid circles) of target caspases thereby inhibiting their catalytic activity. (b) Following zymogen activation caspases are in equilibrium between active (allosteric site closed) and 'zymogen-like' inactive (allosteric site open) conformations. Compound 34 (triangle) binds to the open allosteric site in the dimeric interface thereby trapping the enzyme in an inactive state. Inactive catalytic sites are represented with open circles. For simplicity only caspase monomers are shown. See text for details

\section{P35}

The next caspase inhibitor to be identified was, like CrmA, a viral gene product, but it did not come from viruses that infected mammalian hosts, but from a virus that infects the
Alfalfa looper, Autographa californica. $\mathrm{P} 35,{ }^{34}$ and the related p49 from Spodoptera littoralis nucleopolyhedrovirus ${ }^{35}$ inhibit a broad range of caspases. ${ }^{14,17,36-38}$ P35 not only inhibits insect caspases, but also inhibits many mammalian caspases, mostly with Kds in the low nanomolar range ${ }^{14}$ (Table 1). It is least effective at inhibiting caspases 2 and $9,{ }^{39}$ and is also a relatively weak inhibitor of DRONC, the caspase 9-like initiator caspase from Drosophila, whereas p49 seems capable of inhibiting these caspases as well.

To inhibit caspases, p35 is first cleaved at the exposed reactive site loop $P_{4}-P_{1}$ residues DQMD, but the cleaved polypeptides do not dissociate, as a covalent thiol linkage is formed with the caspase's catalytic cysteine. ${ }^{14,40,41}$ Structural studies of p35 have shown the conformation of this loop and the preceding alpha-helix are essential for caspase inhibition. ${ }^{36,37}$

\section{IAPs}

The first inhibitor of apoptosis protein (IAP) was discovered as baculoviral gene product that could complement Autographa californica nuclear polyhedrosis virus for loss of p35. ${ }^{42}$ They, and cellular homologues discovered subsequently, all bear from one to three baculoviral IAP repeats (BIRs), a novel zinc binding fold of about 70 amino acids. ${ }^{43}$ Although the first IAP described, OpIAP, is able to inhibit cell death, and able to complement AcNPV for mutation to p35, OpIAP does not directly inhibit the catalytic activity of caspases, but presumably acts upstream to prevent activation of caspase zymogens. $^{19}$

NAIP was the first mammalian IAP to be discovered, but rather than having a role in regulation of cell death, it is a 
member of the NACHT-LRR/NOD-LRR/CATERPILLAR/ CLAN family ${ }^{44,45}$ that appears to function in providing innate immunity to infection by bacteria such as Leigonella pneumophila. $^{46,47}$ Although some initial reports suggested it might be able to inhibit caspases in vitro, subsequent studies have shown NAIP cannot directly inhibit caspases at physiological concentrations. ${ }^{29}$

Similarly, although Survivin, an IAP that acts together with aurora kinase $B$ and the inner centromere protein during mitosis, was initially proposed to inhibit caspases, ${ }^{48}$ it is no longer thought to be able to do so. ${ }^{31}$

XIAP, which bears three BIRs, is the most thoroughly characterized mammalian IAP, and also the most potent inhibitor of cell death in vitro. In interactions involving BIR2 and the flanking region just $\mathrm{N}$-terminal to it (the BIR1/BIR2 linker region), XIAP can inhibit caspase 3 and caspase 7 with low nanomolar efficiency ${ }^{24-26}$ (Table 1, Figure 2a). The main interaction involves insertion of an aspartic acid residue from the region flanking BIR2 into the active site of the caspases, but orientation of the inserted peptide is the reverse of that adopted by caspase substrates when they enter the catalytic site. ${ }^{26}$

As well as inhibiting caspase 3 and 7 by this mechanism, XIAP can also inhibit caspase 9 by a different mechanism, in which the third BIR binds to the processed amino-terminus of monomeric caspase 9 , to prevent its dimerization, which is

a

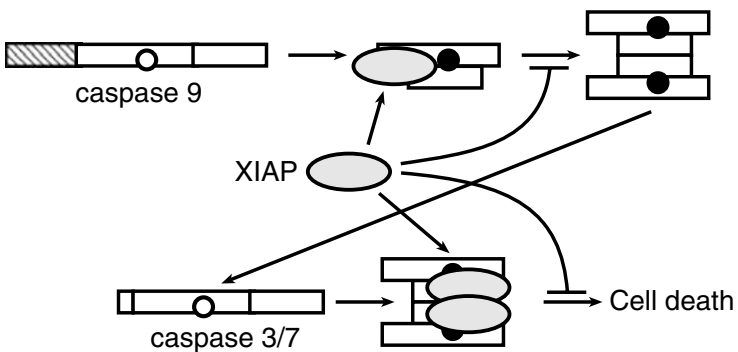

b

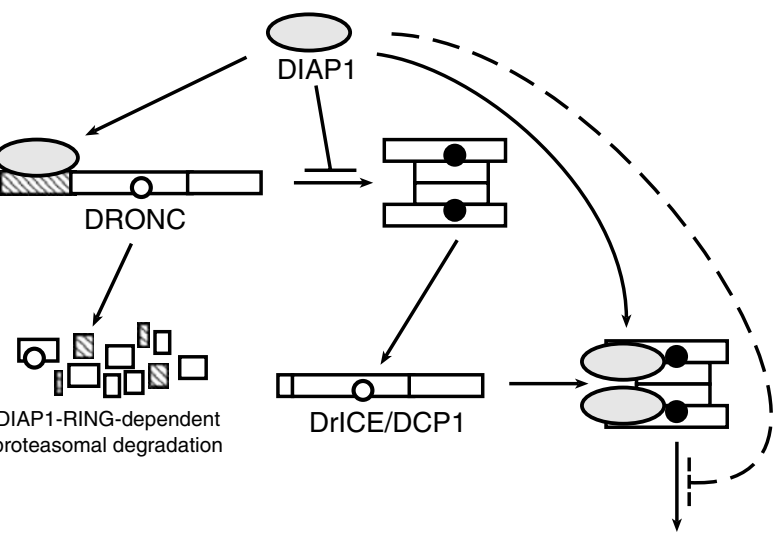

Cell death

Figure 2 Caspase inhibition by IAPs. (a) XIAP can bind to the processed end of the large subunit of caspase 9 thereby preventing its dimerization and subsequent activation. XIAP can also bind to the active catalytic sites (solid circles) of effector caspases, caspase $3 / 7$, thereby blocking their activity. (b) DIAP1 neutralizes DRONC by binding to its pro-domain (hatched box) resulting in DIAP1-RING dependent degradation of DRONC. DIAP1 can also bind to the processed ends of effector caspases, DrICE and DCP1, but may or may not inhibit their activity (indicated with a dashed line). See text for details required for caspase activation. In this way, XIAP inhibits caspase 9 with an IC50 of around $10 \mathrm{nM}^{27,28}$

Like XIAP, cIAP1 and clAP2 have three BIRs and a RING domain. However, although clAP1 and clAP2 are able to bind to caspases, they are not able to inhibit them in physiological circumstances, because their $K_{\mathrm{i}}$ are greater than $5 \mu \mathrm{M},{ }^{29}$ so their ability to inhibit apoptosis is probably indirect rather than by the direct inhibition of caspase activity. Possible mechanisms include: binding to IAP antagonists such as Smac/ Diablo, to reduce the amount available to antagonize XIAP, thereby allowing more XIAP molecules to be free to inhibit caspases; or influencing signalling by $N F-\kappa B$ and MAP kinases, or targeting caspases for ubiquitylation and proteasomal degradation. 29,49

The strongest evidence for a role of IAPs in controlling apoptosis comes not from mammalian experiments but from Drosophila. Whereas deletion of genes for XIAP in the mouse has a very minor phenotype, ${ }^{50}$ deletion of DIAP1 in the fly results in massive, lethal apoptosis. ${ }^{51}$ However, even though they are similar, DIAP1 and XIAP do not act in precisely the same ways. For example, XIAP inhibits caspase 9 activation by binding, via its BIRs, to $\mathrm{N}$ terminally processed caspase 9 , thereby stopping it from dimerizing. DIAP1, on the other hand, binds to the unprocessed form of DRONC, the Drosophila homologue of caspase $9^{20}$ (Figure $2 \mathrm{~b}$ ). Although just the BIRs of XIAP are sufficient to inhibit caspase 9 activation, DIAP1 requires not only its BIRs that bind to DRONC, but also the E3 ligase activity of its RING domain in order to neutralize it. ${ }^{52}$ DIAP1 can also bind to processed effector caspases such as DrICE and DCP1 via conserved IAP-binding motifs (IBMs) in the neo-amino-termini of the large caspase subunits. ${ }^{53}$ Although some groups report DIAP1 inhibits DrICE, ${ }^{21}$ another group suggests that, like clAP1 and clAP2, DIAP1 may not inhibit the proteolytic activity of effector caspases even while bound to them. ${ }^{53}$

\section{Other Caspase Regulators}

In addition to direct inhibitors of caspase activity, several other regulators of caspases have been described that act upstream by indirect mechanisms, rather than by directly blocking catalytic activity. Although these regulators are not the focus of this review, they remain nonetheless extremely interesting proteins by virtue of their potential to modulate caspase activity. For example, using the yeast two hybrid system with the pro-domain of caspase 8 as bait, McDonald et al. reported the identification of caspase 8 and 10 associated RING proteins (CARP1 and CARP2) as inhibitors of apoptosis triggered by death receptor ligation. ${ }^{54}$ Their mechanism of action is yet not fully elucidated, but it is likely that CARPs (also known as human Ring Finger homologous to IAP type or $\mathrm{hRFIs}{ }^{55}$ ) do not directly inhibit caspase proteolytic activity, but may prevent dimerization of procaspases, preventing their activation, or, because they bear a C-terminal RING domain, they may ubiquitylate caspases 8 and 10 and target them for degradation by the proteasome. Similarly, in Drosophila, proteins such as dBruce, a BIR bearing protein and the RING protein Defense repressor 1 (Dnr1) might also be capable of regulating caspases via as yet undetermined mechanisms. ${ }^{56,57}$ 


\section{Synthetic Caspase Inhibitors}

Synthetic caspase inhibitors have been developed both as research tools, and with the hope that they may eventually be used to prevent cell death in the clinic, where they would be of tremendous benefit if they could reduce cell loss in ischaemic vascular diseases, neurodegenerative diseases, and in organ transplant surgery.

Because caspases are cysteine proteases, any inhibitors that can react with the catalytic cysteine, for example, iodoacetamide, are also capable of inhibiting caspases. However, inhibitors that are specific for caspases are more useful for research, and only these could be used in the clinic.

A number of specific and broad-spectrum peptide caspase inhibitors have been developed, the first based upon caspase substrates, for example, the YVHD cleavage site in proIL $1 \beta{ }^{58}$ These inhibitors act as pseudosubstrates for active caspases (Figure 1a) and are therefore competitive inhibitors. Peptides have been linked to chemical groups that serve to block the amino acids and to improve cell permeability, stability and efficacy. These peptide inhibitors range from a single $\mathrm{O}$-methyl-aspartate residue (e.g. benzyloxycarbonyl-aspartyl(OMe)-fluoromethylketone: Boc-Asp-FMK) to tri-peptides (e.g. Boc-val-ala-asp(OMe)-fluoromethylketone: z-VAD-FMK) and tetrapeptides (e.g. YVAD-FMK).

Peptides linked to aldehydes (or nitriles or ketones) are reversible inhibitors (e.g. Ac-DEVD-CHO, Ac-YVAD-CHO) and bind to the catalytic site, but do not irreversibly chemically alter the enzyme. Peptides linked to leaving groups such as halomethylketones (chloro or fluoro), acylomethyl ketones and (phosphinyloxy) methyl ketones are irreversible inhibitors. It has been proposed that irreversible inhibitors (e.g. Ac-DVAD-FMK) bind via a thioester linkage to a transition state oxyanion and the carbonyl oxygen occupies an oxyanion hole in the caspase transition state. ${ }^{59,60}$ Peptide inhibitors display a wide range of specificity and potency against caspase activity with dissociation constants ranging from $\mathrm{pM}$ to low micromolar $(\mu \mathrm{M})$ concentrations (Table 2).

Most synthetic caspase inhibitors are hydrophobic and not very permeable, and could cause nonspecific toxic effects when added at concentrations required to inhibit intracellular caspases. The addition of a carboxy-terminal O-phenoxy group together with an amino-terminal quinolyl group has been reported to significantly improve the efficacy of peptide inhibitors. For example, quinolyl-valyl-O-methylaspartyl-[2,6difluorophenoxy]-methylketone (Q-VD-OPh) effectively inhibits caspase activity at nearly one-tenth the dose required for inhibition by Boc-D-FMK. ${ }^{61}$ The improved leaving properties of the carboxy terminal O-phenoxy group makes this inhibitor more reactive with the active cysteine in caspases, explaining the increased effectiveness of Q-VD-OPh compared with inhibitors linked to fluoromethylketones. The amino terminal quinolyl group alone also decreases the dose of peptide inhibitor required for effect, most likely by increasing cell permeability.

Derivatives of caspase inhibitors as well as caspase substrates have been used as reagents to assay caspase activity. Most commonly caspase substrates are made in which a colorimetric or fluorescent chemical group is linked to the aspartic acid residue of a peptidic caspase substrate so that colour or fluorescence is produced upon substrate cleavage. For example, in DEVD-AFC and DEVD-AMC the AFC (7-amino-4-trifluoromethyl coumarin) and AMC (amino4-methyl coumarin) groups fluoresce following cleavage of the peptide from the substituted coumarin, whereas conjugation to $p$-nitroanilide (e.g. DEVD-pNA) generates a substrate that allows caspase activity to be determined colorimetrically.

Sometimes fluorescent groups (e.g. FITC) are linked to the amino-terminal end of an irreversible peptidic caspase inhibitor, for example, as in FITC-DEVD-FMK. Results using these reagents have to be interpreted with care, because they do not give quantitative signals, and their fluorescence is the same in the presence or absence of active caspases. Rather than becoming fluorescent when they bind to an active caspase, these inhibitors gain specificity because they remain bound to active caspases, whereas the unbound inhibitors are washed away. However, because dead cells are much more permeable than those that are alive, it is possible for much more of the reagent to enter them, so a bright fluorescent signal might be indicative of increased uptake, rather than caspase activity. Indeed, the apparent caspase activity in dying yeast ${ }^{67}$ is most likely an artifact owing to the increased permeability of dead cells. ${ }^{68}$

Until the effects of synthetic caspase inhibitors are confirmed in cells and ultimately in vivo, caution should be exercised when assigning an inhibitor's caspase specificity solely on in vitro determined $K_{\mathrm{i}} \mathrm{s}$, particularly when the $K_{\mathrm{i}} \mathrm{s}$ are derived from cleavage assays that utilize non-physiological,

Table 2 Specificity of chemical caspase inhibitors

\begin{tabular}{|c|c|c|c|c|}
\hline $\begin{array}{l}\text { Caspase } \\
\text { inhibitor }\end{array}$ & Source & Target caspase(s) & $\begin{array}{l}\text { Strength of inhibition (where } \\
\text { known) }\end{array}$ & Reference \\
\hline Q-VD-Oph & Synthetic peptidic & Caspases 1, 3, 8 \& 9 & IC50 25-400 nM & 61 \\
\hline DEVD-CHO & Synthetic peptidic & $\begin{array}{l}\text { Strong inhibitor of caspase } 3 \text { and } \\
\text { caspase } 7\end{array}$ & $K_{\mathrm{i}}<2 \mathrm{nM}$ & 15 \\
\hline zVAD-FMK & Synthetic peptidic & $\begin{array}{l}\text { Inhibits all caspases, but inhibits } \\
\text { caspase } 2 \text { very weakly }\end{array}$ & & 15 \\
\hline IDN-6556 & Synthetic non-peptide, Idun (Pfizer) & $\begin{array}{l}\text { Broad spectrum irreversible } \\
\text { caspase inhibition }\end{array}$ & IC50 $25 \mathrm{nM}$ & 62 \\
\hline Pralnacasan & Synthetic non-peptide (Vertex) & Caspase 1 & & 63,64 \\
\hline M867 & Synthetic non-peptide (Merck-Frosst) & $\begin{array}{l}\text { Reversible, selective effector } \\
\text { caspase inhibitor }\end{array}$ & $\begin{array}{l}K_{\mathrm{i}} 1.4 \mathrm{nM}(\operatorname{casp} 3) \\
K_{\mathrm{i}} 8.9 \mathrm{nM}(\operatorname{casp} 7)\end{array}$ & 65 \\
\hline $\begin{array}{l}\text { Compound } \\
34\end{array}$ & Synthetic non-peptide (Sunesis) & $\begin{array}{l}\text { Targets allosteric site rather than } \\
\text { active site }\end{array}$ & $\begin{array}{l}\text { Inhibits caspase } 1 \text { and caspase } 7 \\
\text { and possibly others }\end{array}$ & 66 \\
\hline
\end{tabular}


peptide-based substrates. Although in vitro derived $K_{\mathrm{i}} \mathrm{S}$ do provide a strong indication of whether an inhibitor is likely to block particular caspases at physiological concentrations, they do not give any indication of possible off-target effects on other enzymes. Ideally, when peptidic caspase inhibitors are used, control experiments should be performed with a compound with the same warhead group, but with a glutamic acid residue in place of the aspartic acid (P1) residue.

\section{Drugs}

Modified peptides generally do not make good pharmaceuticals, owing to problems such as proteolysis and poor cellular permeability. In order to develop drugs to inhibit cell death when it occurs inappropriately, such that caused by ischaemic vascular disease or in neurodegenerative disease, pharmaceutical companies have developed nonpeptide or peptido-mimetic caspase inhibitors. Most of these act like the peptidic caspase inhibitors, that is, they target the caspase's catalytic sites. Recently, researchers at Sunesis ${ }^{66}$ described a different approach, namely to target a cysteine in the caspase's allosteric site so that the drug prevents the caspase from adopting the active conformation (Figure 1b). Their Compound 34 was found in a screen for molecules that formed a thiol linkage with a cysteine in the dimeric interface of caspase 1, and it acts in a way reminiscent of the BIR3 domain of XIAP, which inhibits caspase 9 by binding to the dimer interface to prevent dimerization and activation.

M867, ${ }^{65}$ produced by Merck-Frosst, is a potent reversible caspase inhibitor selective for effector caspases 3 and 7 . Although it was able to block many of the manifestations of apoptosis when administered in vivo, it was ineffective at preventing cell death. These results suggest that irreversible inhibitors, and ones that tackle initiator caspases (e.g. caspase 8, caspase 9) or have broad-spectrum activity, would be more effective in vivo.

Idun, recently acquired by Pfizer, has produced a number of broad-spectrum caspase inhibitors (IDN-8066, -7503, -7436, $-1965,-6556)$. IDN-6556 is a potent, irreversible, broadspectrum caspase inhibitor that strongly inhibited Fasinduced apoptosis in vitro, as well as inhibiting liver injury in the mouse in vivo. In a Phase I clinical trial, oral IDN-6556 was able to reduce levels of liver enzymes in the blood in patients with liver disease, presumably by reducing apoptosis of liver cells. ${ }^{69}$ It is now is in Phase II trials in patients undergoing liver transplantation, with the hope that it will reduce cell death owing to ischaemia-reperfusion injury. ${ }^{62}$

Idun also has described small oxoazepinoindoline caspase inhibitors, IDN-5370 and the more permeable IDN-7866, which prevented apoptosis and promoted the survival of neurons exposed to apoptotic stimuli. ${ }^{70}$ IDN-5370 was reported to significantly reduce cortical infarct size in rats subjected to permanent middle cerebral artery occlusion.

Vertex produced an orally active non-peptide caspase 1 inhibitor, pralnacasan, and has completed a Phase Ila clinical trial in osteoarthritis. ${ }^{71}$ Unfortunately, a phase Ilb trial had to be halted because animal toxicology studies showed liver abnormalities after a 9-month exposure to highdoses.

\section{Conclusions}

Our understanding of the mechanisms of action of caspase inhibitors continues to rapidly expand, and new pharmaceutical caspase inhibitors are being developed. Although some pharmaceutical companies appear to have ceased their caspase inhibitor projects, and no caspase inhibitors have yet reached phase III trials, there are still grounds to be optimistic that caspase inhibitors will eventually be developed that have wide application in the clinic. In the mean time, study of both synthetic and natural caspase inhibitors has provided many new biological insights, some of which may also turn out to have clinical implications. Study of IAPs, for example, has prompted the development of IAP antagonists that show great promise as inducers of cell death, rather than as cell death inhibitors.

Acknowledgements. DLV and BAC are supported by grants from the Australia Research Council and National Health and Medical Research Council.

1. Cerretti DP, Kozlosky CJ, Mosley B, Nelson N, Van NK, Greenstreet TA et al. Molecular cloning of the interleukin-1 beta converting enzyme. Science 1992; 256: 97-100.

2. Thornberry NA, Bull HG, Calaycay JR, Chapman KT, Howard AD, Kostura MJ et al. A novel heterodimeric cysteine protease is required for interleukin-1 beta processing in monocytes. Nature 1992; 356: 768-774.

3. Ray CA, Black RA, Kronheim SR, Greenstreet TA, Sleath PR, Salvesen GS et al. Viral inhibition of inflammation: cowpox virus encodes an inhibitor of the interleukin-1 beta converting enzyme. Cell 1992; 69: 597-604

4. Yuan J, Shaham S, Ledoux S, Ellis HM, Horvitz HR. The $C$. elegans cell death gene ced 3 encodes a protein similar to mammalian interleukin 1 beta converting enzyme. Cell 1993; 75: 641-652.

5. Vaux DL, Weissman IL, Kim SK. Prevention of programmed cell death in Caenorhabditis elegans by human bcl-2. Science 1992; 258: 1955-1957.

6. Miura M, Zhu H, Rotello R, Hartweig EA, Yuan J. Induction of apoptosis in fibroblasts by IL- $1 \beta$-converting enzyme, a mammalian homolog of the $C$. elegans cell death gene ced-3. Cell 1993; 75: 653-660.

7. Kamada S, Funahashi Y, Tsujimoto Y. Caspase-4 and caspase-5, members of the ice/ced3 family of cysteine proteases, are CrmA-inhibitable proteases. Cell Death Differ 1997; 4 : 473-478.

8. Zhou Q, Snipas S, Orth K, Muzio M, Dixit VM, Salvesen GS. Target protease specificity of the viral serpin CrmA - analysis of five caspases. J Biol Chem 1997; 272: 7797-7800.

9. Chinnaiyan AM, O'Rourke K, Tewari M, Dixit VM. Fadd, a novel death domain-containing protein, interacts with the death domain of fas and initiates apoptosis. Cell 1995; 81: 505-512.

10. Enari M, Hug H, Nagata S. Involvement of an ice-like protease in fas-mediated apoptosis. Nature 1995; 375: 78-81.

11. Miura M, Friedlander RM, Yuan JY. Tumor necrosis factor-induced apoptosis is mediated by a CrmA-sensitive cell death pathway. Proc Natl Acad Sci USA 1995; 92: 8318-8322.

12. Tewari M, Dixit VM. Fas- and tumor necrosis factor-induced apoptosis is inhibited by the poxvirus CrmA gene product. J Biol Chem 1995; 270: 3255-3260.

13. Komiyama T, Ray CA, Pickup DJ, Howard AD, Thornberry NA, Peterson EP et al. Inhibition of interleukin-1-beta converting enzyme by the cowpox virus serpin $\mathrm{CrmA}$ - an example of cross-class inhibition. J Biol Chem 1994; 269: 19331-19337.

14. Zhou Q, Krebs JF, Snipas SJ, Price A, Alnemri ES, Tomaselli KJ et al. Interaction of the baculovirus anti-apoptotic protein p35 with caspases - specificity, kinetics, and characterization of the caspase/p35 complex. Biochemistry 1998; 37: 10757-10765.

15. Garcia-Calvo M, Peterson EP, Leiting B, Ruel R, Nicholson DW, Thornberry NA. Inhibition of human caspases by peptide-based and macromolecular inhibitors. J Biol Chem 1998; 273: 32608-32613.

16. Xu G, Rich RL, Steegborn C, Min T, Huang Y, Myszka DG et al. Mutational analyses of the p35-caspase interaction. A bowstring kinetic model of caspase inhibition by p35. J Biol Chem 2003; 278: 5455-5461.

17. Jabbour AM, Ekert PG, Coulson EJ, Knight MJ, Ashley DM, Hawkins CJ. The p35 relative, p49, inhibits mammalian and Drosophila caspases including DRONC and protects against apoptosis. Cell Death Differ 2002; 9: 1311-1320.

18. Zoog SJ, Schiller JJ, Wetter JA, Chejanovsky N, Friesen PD. Baculovirus apoptotic suppressor P49 is a substrate inhibitor of initiator caspases resistant to P35 in vivo. EMBO J 2002; 21: 5130-5140.

19. Kaiser WJ, Vucic D, Miller LK. The Drosophila inhibitor of apoptosis D-IAP1 suppresses cell death induced by the caspase drICE. FEBS Lett 1998; 440: 243-248. 
20. Meier P, Silke J, Leevers SJ, Evan GI. The Drosophila caspase DRONC is regulated by DIAP1. EMBO J 2000; 19: 598-611.

21. Yan N, Wu JW, Chai J, Li W, Shi Y. Molecular mechanisms of DrICE inhibition by DIAP1 and removal of inhibition by Reaper, Hid and Grim. Nat Struct Mol Biol 2004; 11: 420-428.

22. Hawkins CJ, Wang SL, Hay BA. A cloning method to identify caspases and their regulators in yeast: identification of Drosophila IAP1 as an inhibitor of the Drosophila caspase DCP-1. Proc Natl Acad Sci USA 1999; 96: 2885-2890.

23. Hawkins CJ, Yoo SJ, Peterson EP, Wang SL, Vernooy SY, Hay BA. The Drosophila caspase DRONC cleaves following glutamate or aspartate and is regulated by DIAP1, HID, and GRIM. J Biol Chem 2000; 275: 27084-27093.

24. Takahashi R, Deveraux Q, Tamm I, Welsh K, Assamunt N, Salvesen GS et al. A single bir domain of xiap sufficient for inhibiting caspases. J Biol Chem 1998; 273: 7787-7790.

25. Riedl SJ, Renatus M, Schwarzenbacher R, Zhou Q, Sun C, Fesik SW et al. Structural basis for the inhibition of caspase-3 by XIAP. Cell 2001; 104: 791-800.

26. Sun $\mathrm{C}$, Cai M, Gunasekera AH, Meadows RP, Wang H, Chen J et al. NMR structure and mutagenesis of the inhibitor-of-apoptosis protein XIAP. Nature 1999; 401: 818-821.

27. Sun $\mathrm{CH}$, Cai ML, Meadows RP, Xu N, Gunasekera AH, Herrmann J et al. NMR structure and mutagenesis of the third Bir domain of the inhibitor of apoptosis protein XIAP. J Biol Chem 2000; 275: 33777-33781.

28. Shin H, Renatus M, Eckelman BP, Nunes VA, Sampaio CA, Salvesen GS. The BIR domain of IAP-like protein 2 is conformationally unstable: implications for caspase inhibition. Biochem J 2005; 385: 1-10.

29. Eckelman BP, Salvesen GS. The human anti-apoptotic proteins CIAP1 and CIAP2 bind but do not inhibit caspases. J Biol Chem 2006; 281: 3254-3260.

30. Vucic D, Franklin MC, Wallweber HJ, Das K, Eckelman BP, Shin $\mathrm{H}$ et al. Engineering ML-IAP to produce an extraordinarily potent caspase 9 inhibitor: implications for Smac-dependent anti-apoptotic activity of ML-IAP. Biochem J 2005; 385: 11-20.

31. Banks DP, Plescia J, Altieri DC, Chen J, Rosenberg SH, Zhang HC et al. Survivin does not inhibit caspase-3 activity. Blood 2000; 96: 4002-4003.

32. Strasser A, O'Connor L, Dixit VM. Apoptosis signaling. Ann Rev Biochem 2000; 69: 217-245.

33. Patston PA, Gettins P, Beechem J, Schapira M. Mechanism of serpin action: evidence that C1 inhibitor functions as a suicide substrate. Biochemistry 1991; 30: 8876-8882.

34. Clem RJ, Fechheimer M, Miller LK. Prevention of apoptosis by a baculovirus gene during infection of insect cells. Science 1991; 254: 1388-1390.

35. Du QS, Lehavi D, Faktor O, Qi YP, Chejanovsky N. Isolation of an apoptosis suppressor gene of the Spodoptera littoralis nucleopolyhedrovirus. J Virol 1999; 73: 1278-1285.

36. Fisher AJ, dela Cruz W, Zoog SJ, Schneider CL, Friesen PD. Crystal structure of baculovirus P35: role of a novel reactive site loon in apoptotic caspase inhibition. EMBO J 1999; 18: 2031-2039.

37. dela Cruz WP, Friesen PD, Fisher AJ. Crystal structure of baculovirus P35 reveals a nove conformational change in the reactive site loop after caspase cleavage. J Biol Chem 2001; 276: 32933-32939

38. Xu G, Cirilli M, Huang Y, Rich RL, Myszka DG, Wu H. Covalent inhibition revealed by the crystal structure of the caspase-8/p35 complex. Nature 2001; 410: 494-497.

39. Eddins MJ, Lemongello D, Friesen PD, Fisher AJ. Crystallization and low-resolution structure of an effector-caspase/P35 complex: similarities and differences to an initiatorcaspase/P35 complex. Acta Crystallogr 2002; 58: 299-302.

40. Bertin J, Mendrysa SM, Lacount DJ, Gaur S, Krebs JF, Armstrong RC et al. Apoptotic suppression by baculovirus p35 involves cleavage by and inhibition of a virus-induced ced3/ice-like protease. J Virol 1996; 70: 6251-6259.

41. Bump NJ, Hackett M, Hugunin M, Seshagiri S, Brady K, Chen P et al. Inhibition of ice family proteases by baculovirus antiapoptotic protein p35. Science 1995; 269: 1885-1888.

42. Crook NE, Clem RJ, Miller LK. An apoptosis inhibiting baculovirus gene with a zinc finger like motif. J Virol 1993; 67: 2168-2174.

43. Hinds MG, Norton RS, Vaux DL, Day CL. Solution structure of a baculoviral inhibitor of apoptosis (IAP) repeat. Nat Struct Biol 1999; 6: 648-651.

44. Ting JP, Davis BK. Caterpiller: a novel gene family important in immunity, cell death, and diseases. Ann Rev Immunol 2005; 23: 387-414.

45. Damiano JS, Newman RM, Reed JC. Multiple roles of CLAN (caspase-associated recruitment domain, leucine-rich repeat, and NAIP CIIA HET-E, and TP1-containing protein) in the mammalian innate immune response. J Immunol 2004; 173: 6338-6345.

46. Diez E, Lee SH, Gauthier S, Yaraghi Z, Tremblay M, Vidal S et al. Birc1e is the gene within the Lgn1 locus associated with resistance to Legionella pneumophila. Nat Genet 2003; 33 $55-60$.
47. Wright EK, Goodart SA, Growney JD, Hadinoto V, Endrizzi MG, Long EM et al. Naip5 affects host susceptibility to the intracellular pathogen Legionella pneumophila. Curr Biol 2003; 13: 27-36.

48. Li F, Ackermann EJ, Bennett CF, Rothermel AL, Plescia J, Tognin S et al. Pleiotropic celldivision defects and apoptosis induced by interference with survivin function. Nat Cell Bio 1999; 1: 461-466.

49. Vaux DL, Silke J. IAPs, RINGs and ubiquitylation. Nat Rev Mol Cell Biol 2005; 6: 287-297.

50. Harlin H, Reffey SB, Duckett CS, Lindsten T, Thompson CB. Characterization of XIAPdeficient mice. Mol Cell Biol 2001; 21: 3604-3608.

51. Wang SL, Hawkins CJ, Yoo SJ, Muller HAJ, Hay BA. The Drosophila caspase inhibitor DIAP1 is essential for cell survival and is negatively regulated by HID. Cell 1999; 98 : 453-463.

52. Wilson R, Goyal L, Ditzel M, Zachariou A, Baker DA, Agapite J et al. The DIAP1 RING finger mediates ubiquitination of Dronc and is indispensable for regulating apoptosis. Nat Cell Biol 2002; 4: 445-450.

53. Tenev $T$, Zachariou A, Wilson R, Ditzel M, Meier P. IAPs are functionally non-equivalent and regulate effector caspases through distinct mechanisms. Nat Cell Biol 2004; 7 : 70-77.

54. McDonald III ER, El-Deiry WS. Suppression of caspase-8- and -10-associated RING proteins results in sensitization to death ligands and inhibition of tumor cell growth. Proc Natl Acad Sci USA 2004; 101: 6170-6175.

55. Sasaki S, Nakamura T, Arakawa $\mathrm{H}$, Mori M, Watanabe T, Nagawa $\mathrm{H}$ et al. Isolation and characterization of a novel gene, hRFI, preferentially expressed in esophageal cancer. Oncogene 2002; 21: 5024-5030.

56. Foley E, O'Farrell PH. Functional dissection of an innate immune response by a genomewide RNAi screen. PLoS Biol 2004; 2: 1091-1106.

57. Vernooy SY, Chow V, Su J, Verbrugghe K, Yang J, Cole S et al. Drosophila Bruce can potently suppress Rpr- and Grim-dependent but not hid-dependent cell death. Curr Biol 2002; 12: 1164-1168.

58. Rano TA, Timkey T, Peterson EP, Rotonda J, Nicholson DW, Becker JW et al. A combinatorial approach for determining protease specificities - application to interleukin-1. beta converting enzyme (ice). Chem Biol 1997; 4: 149-155.

59. Mittl PR, Di Marco S, Krebs JF, Bai X, Karanewsky DS, Priestle JP et al. Structure of recombinant human CPP32 in complex with the tetrapeptide acetyl-Asp-Val-Ala-Asp fluoromethyl ketone. J Biol Chem 1997; 272: 6539-6547.

60. Walker NPC, Talanian RV, Brady KD, Dang LC, Bump NJ, Ferenz CR et al. Crysta structure of the cysteine protease interleukin-1- $\beta$-converting enzyme: $A(p 20 / p 10)_{2}$ homodimer. Cell 1994; 78: 343-352.

61. Caserta TM, Smith AN, Gultice AD, Reedy MA, Brown TL, Q-VD-OPh, a broad spectrum caspase inhibitor with potent antiapoptotic properties. Apoptosis 2003; 8: 345-352.

62. Linton SD, Aja T, Armstrong RA, Bai X, Chen LS, Chen N et al. First-in-class pan caspase inhibitor developed for the treatment of liver disease. J Med Chem 2005; 48 : 6779-6782.

63. Linton SD. Caspase inhibitors: a pharmaceutical industry perspective. Curr Top Med Chem 2005; 5: 1697-1717.

64. Siegmund B, Zeitz M. Pralnacasan (vertex pharmaceuticals). IDrugs 2003; 6: 154-158.

65. Methot N, Huang J, Coulombe N, Vaillancourt JP, Rasper D, Tam J et al. Differentia efficacy of caspase inhibitors on apoptosis markers during sepsis in rats and implication for fractional inhibition requirements for therapeutics. J Exp Med 2004; 199: 199-207.

66. Scheer JM, Romanowski MJ, Wells JA. A common allosteric site and mechanism in caspases. Proc Natl Acad Sci USA 2006; 103: 7595-7600

67. Madeo F, Herker E, Maldener C, Wissing S, Lachelt S, Herian M et al. A caspase-related protease regulates apoptosis in yeast. Mol Cell 2002; 9: 911-917.

68. Wysocki R, Kron SJ. Yeast cell death during DNA damage arrest is independent of caspase or reactive oxygen species. J Cell Biol 2004; 166: 311-316.

69. Valentino KL, Gutierrez M, Sanchez R, Winship MJ, Shapiro DA. First clinical trial of a novel caspase inhibitor: anti-apoptotic caspase inhibitor, IDN-6556, improves liver enzymes. Int $J$ Clin Pharmacol Ther 2003; 41: 441-449.

70. Deckwerth TL, Adams LM, Wiessner C, Allegrini PR, Rudin M, Sauter A et al. Long-term protection of brain tissue from cerebral ischemia by peripherally administered peptidomimetic caspase inhibitors. Drug Dev Res 2001; 52: 579-586.

71. Rudolphi K, Gerwin N, Verzijl N, van der Kraan P, van den Berg W. Pralnacasan, an inhibitor of interleukin-1beta converting enzyme, reduces joint damage in two murine models of osteoarthritis. Osteoarthritis Cartilage 2003; 11: 738-746. 